\title{
Reflecties op de kwaliteit van de jaarverslaggeving
}

\section{Dick Feenstra}

SAMENVATTING Een reeks van schandalen op het gebied van de externe verslaggeving heeft in binnen- en buitenland de afgelopen twintig jaren geleid tot een hernieuwde bezinning op de doelstellingen en de inhoud ervan. Ook de regelgeving met betrekking tot de externe verslaggeving is aangepast; de eisen die heden ten dage worden gesteld aan de jaarrekening en het jaarverslag zijn aanzienlijk strenger dan twintig jaren geleden. In de managementliteratuur zijn in de jaren tachtig en negentig vele voorstellen gedaan ter verbetering van het functioneren van organisaties; in dit artikel worden hiervan zes voorbeelden genoemd en worden er twee nader toegelicht. In de literatuur over de kwaliteit van de externe verslaggeving is van deze voorstellen evenwel weinig tot niets terug te vinden, zoals blijkt uit de bespreking van enkele studies waarin het begrip kwaliteit soms relatief eng en soms relatief breed wordt geïnterpreteerd. In het artikel komen diverse interpretaties van het kwaliteitsbegrip aan de orde. Kwaliteitsdiscussies waarin keuzeproblemen centraal worden gesteld door middel van de begrippen 'accounting choice' en 'impression management' zijn in de internationale verslaggevingsliteratuur ruimschoots aanwezig. Kwaliteitsdiscussies in de Nederlandstalige literatuur gaan veelal uit van een relatief enge interpretatie van het begrip kwaliteit. Empirische onderzoekingen hebben veelal een 'compliance'-karakter; 'accounting choice'- en 'impression management'-studies komen niet voor. In de afgelopen tien jaren hebben zich in Nederland belangrijke institutionele en verslaggevingsinhoudelijke ontwikkelingen voltrokken.

\section{RELEVANTIE VOOR DE PRAKTIJK De kwaliteit van de externe verslaggeving wordt in} de nationale en internationale literatuur op verschillende wijzen geïnterpreteerd, waarbij relatief enge en relatief brede interpretaties kunnen worden onderkend. De bedoelde literatuur benadert het begrip kwaliteit niet vanuit de alom bekende 'kwalitatieve kenmerken', maar vanuit een breder perspectief, bijvoorbeeld als 'accounting choice'-probleem of als middel ter beïnvloeding van de gebruikers van de externe verslaggeving.

\section{Inleiding}

Reeds vanaf de jaren zeventig van de vorige eeuw worden we min of meer regelmatig geconfronteerd met schan- dalen op het terrein van de externe verslaggeving. In de jaarrapporten (jaarrekeningen en directieverslagen) van diverse ondernemingen werd de winst vaak te hoog voorgesteld en klopten de balanswaarderingen niet. ${ }^{1}$ De bedoelde schandalen hebben veel aandacht gekregen in zowel de populaire pers (bijvoorbeeld Het Financieele Dagblad) als in de vakliteratuur. Geruchtmakende gevallen in Nederland waren onder meer: RVS (tweede helft jaren zeventig; leidde tot de parlementaire enquêtecommissie-Van Dijk: het betrof hier winststuring en manipulatie met voorzieningen); BAAN (jaren negentig; door middel van leveringen door privéondernemingen van directieleden werd de winst verhoogd); AHOLD (eind jaren negentig en begin deze eeuw; door ongerechtvaardigde consolidaties werd extra omzet gecreëerd) en Koninklijke Olie (eind jaren negentig en begin deze eeuw; reservevoorraden werden systematisch te hoog geschat). In het buitenland hebben in het afgelopen decennium met name verslaggevingsaffaires rond ENRON (Verenigde Staten van Amerika), Parmalat (Italië) en Lernout \& Hauspie (België) veel aandacht getrokken. In de literatuur is uitgebreid ingegaan op de motieven voor het gedrag van de zojuist genoemde en andere ondernemingen, alsmede op de toegepaste technieken (o.a. Fields, Lys en Vincent, 2001; Mulford en Comiskey, 2002; Nelson, Elliot en Tarpley, 2003; Francis, Huang, Khurana en Pereira, 2009). In oudere overzichtsartikelen werden reeds diverse determinanten gesuggereerd (o.a. Lev en Ohlson, 1982; Bernard, 1989). In verreweg de meeste studies blijkt de 'accounting choice'-problematiek benaderd te worden vanuit het paradigma van 'capital market-based accounting research', waarbij wordt ingegaan op onder andere de gevolgen van marktimperfecties, zoals informatieasymmetrie. Het bestek van dit artikel biedt geen ruimte voor een uitgebreide studie van de 'accounting choice'-problematiek (zie Fields et al., 2001). Wel wijzen we nog op de toepassing van andere paradigmata: experimentele, analytische en gedragswetenschappelijke paradigmata. Op één ervan gaan wij hier kort in, te weten de 
gedragswetenschappelijke theorie van impressiemanagement (IM).

Hooghiemstra (2000, p. 60) definieert IM als 'a field of study within social psychology studying how individuals present themselves to others to be perceived favourably by others'. Toegepast op de externe verslaggeving gaat het volgens Clatworthy en Jones (2001, p. 311) om 'attempts to control and manipulate the impression conveyed to users of accounting information'. Zie voor de vele vormen en strategieën van IM, waaronder 'earnings management' en het bewust beïnvloeden van de leesbaarheid van externe verslagen, Merkl-Davies en Brennan (2007). IM beïnvloedt de kwaliteit van de externe verslaggeving met als mogelijk gevolg verkeerde vermogensallocatiebeslissingen (MerklDavies en Brennan, 2007, p. 1).

Zowel het dominante 'capital market-based accounting research'-paradigma als het gedragswetenschappelijke paradigma IM brengt de kwaliteit van de externe verslaggeving dus in verband met vermogensallocatiebeslissingen. Beide paradigmata benadrukken het belang van het concept kwaliteit.

In dit artikel vragen wij ons af op welke wijze het concept kwaliteit in de verslaggevingsliteratuur wordt geoperationaliseerd. Er blijken veel interpretaties van het concept te bestaan, zowel enge als zeer brede. In paragraaf 2 geven we een overzicht van diverse interpretaties; de enge interpretaties behandelen we in paragraaf 2.2, terwijl relatief brede interpretaties in paragraaf 2.3 worden besproken. In paragraaf 3 komt de vraag aan de orde of en in hoeverre de verschillende interpretaties zijn beïnvloed door het deel van de managementliteratuur waarin suggesties worden gedaan voor een op continuïteit gerichte bedrijfsvoering. Ten slotte vragen we ons in paragraaf 4 af welke implicaties de in het voorgaande besproken opvattingen hebben gehad voor Nederland gedurende de periode 2000-2010. Paragraaf 5 bevat de conclusies van dit artikel.

Het artikel beoogt bij te dragen aan de bezinning op het begrip kwaliteit van de externe verslaggeving. Kwaliteit is een begrip dat op vele uiteenlopende wijzen geïnterpreteerd kan worden. Ter vermijding van misverstanden is het gewenst duidelijk aan te geven wat wel en wat niet wordt bedoeld.

Het artikel beoogt niet een overzicht te geven van (beweerde) gebreken van het traditionele model van de externe verslaggeving in de vorm van jaarrapporten, omvattende onder meer het directieverslag en de jaarrekening. Dit traditionele model zou te sterk op het verleden zijn georiënteerd, te kwantitatief en te financieel van aard zijn, waardoor voor de waardecreatie belangrijke grootheden, zoals immateriële activa, buiten beeld blijven (zie o.a. AICPA, 1994; FASB, 2001; ICAEW, 2003). In de Verenigde Staten (SEC, 2003) en in het Verenigd Koninkrijk(ASB, 2003) zijn inmiddels voorschriften ontwikkeld om door middel van narratieve informatie in jaarrapporten de kloof tussen het traditionele model en de moderne visie te verkleinen. Dit brengt ons terug bij het doel van dit artikel, of, zoals Beattie, Mclnnes en Fearnley (2004, p. 205) het formuleren: '... it is now recognised that there is an urgent need to develop disclosure metrics to facilitate research into voluntary disclosure and quality.'

Een eerste stap wordt in dit artikel gezet in de vorm van bezinning op het begrip kwaliteit. De oproep om 'disclosure metrics' te ontwikkelen voor de mate van openheid in de jaarverslaggeving vergt een afzonderlijke studie (zie bijv. Botosan, 1997; Lang en Lundholm, 2000; Beattie et al. 2004). Een min of meer volledige behandeling van het kwaliteitsbegrip binnen de diverse paradigmata van de externe verslaggeving gaat het bestek van dit artikel te boven (zie Knoops, 2001, 2010).

Het is nadrukkelijk niet de bedoeling de zogenaamde kwalitatieve kenmerken van de externe verslaggeving, zoals geformuleerd door bijvoorbeeld FASB, IASB en Raad voor de Jaarverslaggeving, gedetailleerd te bespreken. Enkele hoofdlijnen zijn in een bijlage samengevat.

\section{Kwaliteit en jaarverslaggeving}

\subsection{Inleiding}

Het begrip kwaliteit van de informatieverstrekking kan op diverse manieren worden geïnterpreteerd en gemeten (Supplement The Accounting Review 2002; Beattie et al, 2004; Francis, Olsson en Schipper, 2006). In verschillende studies en stellingnames van de FASB, de IASB en de RJ wordt de kwaliteit vereenzelvigd met het naleven van zogenoemde kwalitatieve kenmerken, waarvan volgens de IASB (2010) de belangrijkste zijn: relevantie, getrouwe weergave, vergelijkbaarheid, verifieerbaarheid, tijdigheid en begrijpelijkheid (zie de bijlage en Knoops, 2010, p.94 en pp. 100-102). Het vaststellen in hoeverre concrete informatie aan deze kenmerken voldoet, is lastig. Het aanwezig zijn van een goedkeurende accountantsverklaring bij een financiële verantwoording wordt door velen gemakshalve opgevat als afdoende bewijs voor voldoende kwaliteit. Voor vele accountingonderzoekers volstaat een dergelijke bewijsvoering niet vanwege de achterliggende subjectiviteit en onbepaaldheid. Gezocht wordt daarom naar scherper gedefinieerde maatstaven die objectief gemeten kunnen worden.

In deze paragraaf bespreken we diverse enge (paragraaf 2.2) en relatief brede (paragraaf 2.3) interpretaties van het begrip kwaliteit. 


\subsection{Kwaliteit en jaarrekening}

In de internationale literatuur wordt de kwaliteit van de jaarrekening geacht bepaald te worden door het begrip 'earnings quality' (kwaliteit van de winst). Francis et al. (2006) geven in een uitgebreid overzichtsartikel aan hoe het 'earnings quality'-onderzoek vorm heeft gekregen. In het supplement van The Accounting Review (2002) was eerder al verslag gedaan van een 'Quality of Earnings Conference' van de American Accounting Association: in een aantal artikelen werd de kwaliteit van de winst vanuit zes verschillende perspectieven beschouwd (o.a. vanuit de visie van financiële analisten en vanuit een 'earnings management'-perspectief). Francis et al. (2006) gaan in een meer recent overzichtsartikel uit van het 'capital market-based'onderzoek, waarbij het gebruik van accountinginformatie door vermogensmarktparticipanten van fundamenteel belang wordt geacht voor vermogensallocatiebeslissingen. Binnen het gekozen paradigma wordt de kwaliteit van de winst gezien als een samenvattende maatstaf voor de kwaliteit van de externe financiële verslaggeving. Het overzichtsartikel geeft een niet-uitputtende opsomming van de vele door accountingonderzoekers gehanteerde indicatoren van de kwaliteit van de winst. Francis et al. (2006, p. 263) zelf benadrukken dat kwaliteit van de winst nauw samenhangt met relatief stabiele winstcijfers ('permanent earnings'). Tot de twaalf door hen besproken indicatoren behoren onder andere: de kwaliteit van de 'accruals', de duurzaamheid ('persistance') van de winst, de voorspelbaarheid, het ontbreken van uitschieters in de winstcijfers ('smoothness'), de tijdigheid en de toegepaste mate van voorzichtigheid ('conservatism').

In de Nederlandstalige literatuur was door Kamp (2002, p. 39) ook al gewezen op het verband tussen goede winstkwaliteit en de door Francis et al. (2006) genoemde indicatoren inzake stabiliteit, duurzaamheid en de kwaliteit van de 'accruals'. Dechow en Schrand (2004) stellen eveneens dat de kwaliteit van de winst hoger is naarmate de winst voor een groter deel voortkomt uit de 'core business' en een stabieler patroon vertoont.

In een recent gepubliceerde studie hebben Gaio en Raposo (in press) meer dan 7000 ondernemingen in 38 landen over de periode 1990-2003 onderzocht op de kwaliteit van de winst. In het kader van een 'capital market-based accounting research'-paradigma tonen de auteurs een positief verband aan tussen ondernemingswaarde en de kwaliteit van de winst. Deze kwaliteit wordt geoperationaliseerd door middel van zeven attributen, waartoe onder andere de kwaliteit van de 'accruals', de tijdigheid en de mate van voorzichtigheid behoren. Het verband blijkt relatief sterk te zijn indien ondernemingen goede investeringsperspectieven hebben en de beschermingsconstructies ten behoeve van aandeelhouders relatief zwak zijn.
Naar aanleiding van de zojuist genoemde studies rijst de vraag waardoor de kwaliteit van de jaarrekening wordt bepaald. Dit is duidelijk een geheel andere vraag dan die naar de meting ervan. Francis et al. (2006, p. 276) maken daarom een onderscheid tussen 'innate sources' en 'reporting sources'. Tot de 'innate sources' behoren operationele en omgevingsfactoren (bijvoorbeeld het businessmodel annex de interne en externe risico's). Tot de 'reporting sources' behoren (p. 276): 'management decisions, information systems, auditing, governance structures, regulation and standards'.

In paragraaf 2.3 noemen we enkele studies waarin bij de meting van de kwaliteit beter de achterliggende kwaliteitsbepalende factoren in beschouwing worden genomen.

\subsection{Relatief breed opgezette kwaliteitsmetingen}

Een in Nederland bekende poging tot definiëring en meting van de kwaliteit van de jaarverslaggeving is die van Hoogendoorn en Mertens (2001). De onderzoekers leggen een verband tussen de hoeveelheid verstrekte informatie en de eisen en verwachtingen van de ontvangers ervan; een interpretatie die lijkt op hetgeen in de marketingliteratuur gangbaar is (Leeflang, 1993, p. 231). Hoogendoorn en Mertens (2001) meten de kwaliteit door middel van een 'disclosure-index' waarmee wordt aangegeven in hoeverre de verstrekte informatie-elementen tegemoet komen aan de eisen en verwachtingen van financieel analisten (Hoogendoorn en Mertens, 2001, p. 411 e.v.). Weliswaar wordt ook de institutionele structuur van wet- en regelgeving als een 'belangrijke dimensie van kwaliteit' (p. 408) gezien, maar deze opvatting wordt door Hoogendoorn en Mertens niet verder geoperationaliseerd en gekwantificeerd.

Het onderzoek van Hoogendoorn en Mertens (2001) roept onder meer de vraag op of de verstrekking van meer informatie altijd tot kwaliteitsverbetering leidt. Onze zienswijze is dat dat wel kan, maar niet noodzakelijkerwijs het geval hoeft te zijn: er kan 'information overload' ontstaan en ook de leesbaarheid kan in het gedrang komen. ${ }^{2,3}$ In de internationale literatuur wordt in samenhang hiermee wel gesteld dat vrijwillige informatieverstrekking ('voluntary disclosure') tot meer transparantie kan leiden en dientengevolge tot een lagere vermogenskostenvoet (bijv. Leuz en Verrecchia, 2003; Francis, Khurana en Pereira, 2005; Botosan, 2006).

Een brede interpretatie van het begrip kwaliteit, waarbij de medebepalende achterliggende institutionele factoren wel bij de meting betrokken worden, treffen we aan bij Verriest (2009) (zie ook Leuz, Nanda en Wysocki, 2003). Verriest (2009, p. 48) definieert kwaliteit weliswaar gelijk an Hoogendoorn en Mertens ('the usefulness of accounting information for those outside the company'), maar zijn 
operationalisering is geheel afwijkend; hij beperkt zich daarbij niet tot louter de financiële verslaggeving. Het grote verschil is gelegen in de wijze waarop onderzoekstechnisch met instituties wordt omgegaan. Het onderzoek van Verriest is primair gericht op het meten van de verslaggevingskwaliteit van landen en niet van ondernemingen. Zoals eerder gesteld onderkennen Hoogendoorn en Mertens (2001) de dimensie institutionele structuur, maar een nadere uitwerking ontbreekt bij hen. Verriest interpreteert kwaliteit zeer breed als het product van zowel wet- en regelgeving (eigendomsrechten- en structuren, corporate governance en verslaggevingsregels), afdwingbaarheid van het recht, institutionele kenmerken (democratisch gehalte van een staat, mate van staatsinterventie en de ontwikkeling van financiële markten) en hun onderlinge relaties. Het begrip kwaliteit wordt door Verriest (2009) geoperationaliseerd door middel van een 'Composite Financial Reporting Quality Score', een maatstaf die wordt berekend op basis van de scores op een viertal submaatstaven, te weten: 'earnings smoothing', 'earnings discretion', 'timely loss recognition' en 'earnings informativeness'. Voor elk van deze submaatstaven als kwaliteitsproxy kan (gezaghebbende) steun worden gevonden in de internationale literatuur. Wij geven voor elke submaatstaf één recente literatuurverwijzing:

- Voor 'earnings smoothing': Myers, Myers en Skinner (2007); de vraag is in hoeverre het egaliseren van cashflows met behulp van 'accruals' de winstkwaliteit beïnvloedt. Hoe meer er geëgaliseerd wordt, des te lager de kwaliteit is.

- Voor 'earnings discretion': Skinner en Sloan (2002); de vraag is nu in hoeverre met behulp van 'accruals' de winst wordt overschat. Hoe sterker de winst wordt overschat, des te lager de kwaliteit is.

- Voor 'timely loss recognition': Ball en Shivakumar (2005); in hoeverre worden verliezen sneller onderkend dan winsten? Hoe conservatiever de winst wordt berekend, des te hoger de kwaliteit is.

- Voor 'earnings informativeness': Francis, Schipper en Vincent (2005); in hoeverre reageert de vermogensmarkt op de winst per aandeel over eenzelfde periode (de 'earnings response coefficient')? Hoe sterker het verband, des te hoger de kwaliteit van de winst is.

De belangrijkste conclusie uit het omvangrijke internationale onderzoek van Verriest (2009) luidt dat de kwaliteit van de verslaggeving niet primair wordt bepaald door het type verslaggevingsstandaarden, maar door institutionele factoren. De belangrijkste daarvan zijn: de mate waarin minderheidsaandeelhouders beschermd zijn, de regulering van financiële markten en producten, de afdwingbaarheid van het recht en de inmenging van de staat. Op ondernemingsniveau stelt Verriest dat de aandeelhoudersstructuur, de corporate governance en de auditkwaliteit een sterke impact hebben op de kwaliteit van de verslaggeving. Volgens Verriest zullen zelfs bij voor alle landen gelijkluidende verslaggevingsregels tussen landen implementatieverschillen gaan ontstaan door verschillen in institutionele achtergronden. De hoogste kwaliteitsscores berekende Verriest voor Australië, Zweden en het Verenigd Koninkrijk (tabel 2.2, p. 74). De Verenigde Staten scoorde een zesde plaats; Nederland moest genoegen nemen met een bescheiden negentiende plaats. Het is dit brede en complexe kwaliteitsconcept dat ons inziens goede mogelijkheden biedt voor toekomstig onderzoek, zoals: onderzoek naar kwaliteitswijzigingen in relatie tot ingrijpende wijzigingen in wet- en regelgeving; onderzoek naar kwaliteitsontwikkelingen in de tijd gezien; analyses per verslaggevingsthema.

\section{Invloed managementliteratuur?}

Hoewel de zojuist besproken studies mede de enge interpretatie van kwaliteit blijken te omvatten, rijst een nieuwe vraag: is er afdoende rekening gehouden met factoren die van invloed zijn op de continuïteit van organisaties? Welke factoren dit zijn, kan bijvoorbeeld blijken door kennis te nemen van de volgende zes studies uit de algemene managementliteratuur 4 :

- Kempen: Bedrijfsdiagnose alias management audit (1980);

- Peters en Waterman: Excellente ondernemingen (1982);

- Van der Zwan: Koplopers en achterblijvers (1990);

- Collins en Porras: Built to last (1994);

- De Geus: De levende onderneming (1997);

- Van Witteloostuijn: De anorexiastrategie (1999).

Wij beperken ons hier bij wijze van voorbeeld tot enkele korte opmerkingen over twee van deze zes studies, te weten Kempen (1980) en Peters en Waterman (1982). Hoewel er hier sprake is van relatief oude literatuur zijn vele van in deze studies gehanteerde begrippen contextonafhankelijk. Globalisering en/of automatisering zijn dan van geringere betekenis.

Kempen (1980) heeft ten behoeve van het accountantskantoor Van Dien \& Co. een methode voor preventief organisatieonderzoek ontwikkeld, met als doel om in gezonde organisaties zwakheden vroegtijdig te signaleren (p. 111). Hij maakt in dit kader een onderscheid tussen bedrijfsindicatoren en omgevingsindicatoren. De bedrijfsindicatoren zijn: ambitie, streefkracht, omgevingszin, beweeglijkheid, kwetsbaarheid, kwaliteit management en financiële conditie. De omgevingsindicatoren zijn: brancheontwikkelingen en maatschappelijk belang. Per indicator wordt een (gedeeltelijk subjectieve) waardering bepaald op basis van interviews en waarneming van documenten. Het management van een onder- 
zochte organisatie bespreekt deze waarderingen vervolgens met de consultant teneinde in gemeenschappelijk overleg een actieplan op te zetten om geconstateerde zwakke punten te verhelpen.

Het internationaal geruchtmakende boek van Peters en Waterman (1982) richtte zich in eerste instantie op 'excellente' Amerikaanse ondernemingen, maar is later uitgebreid tot Europese en Japanse ondernemingen. De kwalificatie excellent is daardoor veel breder uitgewerkt dan aanvankelijk het geval was voor Amerikaanse ondernemingen. Een van de inzichten die sterk wordt benadrukt, is het belang van de betekenis die dient te worden toegekend aan de cultuur van de organisatie. Onder cultuur wordt hierbij onder andere verstaan de stijl van leidinggeven, de patronen van besluitvorming, het stelsel van waarden die worden nagestreefd en soortgelijke ogenschijnlijke ongrijpbare zaken. Een tweede bevinding, die als een rode draad door het hele boek loopt, is de onderkenning dat excellente ondernemingen zich vooral onderscheiden door hun bereidheid tot verandering. Ondanks hun succes stellen deze ondernemingen zich voortdurend open voor nieuwe inzichten en veranderingen, zowel van binnen als van buiten.

De zes genoemde studies munten alle uit in min of meer integrale analyses van het functioneren en presteren van het management van organisaties. De analyses hebben geleid tot diverse algemene aanbevelingen, die in vrijwel alle zes studies zijn terug te vinden. Bijvoorbeeld:

- organisaties dienen zich te beperken tot de 'core business';

- de visie van de organisatie dient naar binnen breed gedragen te worden;

- het beleid dient consistent te zijn;

- het financiële beleid dient conservatief te zijn;

- het personeel dient zorgvuldig gescreend en opgeleid te zijn en behoort bovendien goed geïnformeerd te zijn;

- organisaties dienen klantgericht te zijn;

- organisaties dienen zich op intelligente wijze te kunnen aanpassen aan veranderende omstandigheden.

De in deze paragraaf genoemde factoren worden door Francis et al. (2006) 'innate sources' genoemd (zie paragraaf 2.2). In de door ons geselecteerde kwaliteitsstudies is relatief weinig terug te vinden van de aanbevelingen bij de operationalisering van het begrip kwaliteit. Operationalisering is blijkbaar een groot probleem. Hier is duidelijk ruimte voor nader onderzoek.

\section{Reflecties op de Nederlandse literatuur}

Het Nederlandse onderzoek naar de kwaliteit van de externe verslaggeving is sinds het onderzoek van Hoogendoorn en Mertens (2001) nog steeds relatief vaak gericht op de naleving van wet- en regelgeving (het zogenaamde 'compliance'-onderzoek). De diverse edities van Het jaar verslagen (sinds 1996) en twee recente MAB-'specials' (2010-2011) illustreren dit fraai. Kan het zijn dat men nog steeds teert op de lofprijzingen in gezaghebbende internationale leerboeken, zoals die van Nobes en Parker (2002, met name de bijdrage van Parker in hoofdstuk 9) en Radebaugh en Gray (2002)? Laatstgenoemden stellen bijvoorbeeld op p. 55: 'The Netherlands is famous for its business economics approach to accounting.'

Zijn we eigenlijk na de onderzoekingen van enerzijds Hoogendoorn en Mertens (2001) en anderzijds Kamp (2002), nog niet veel verder dan 1999 toen Traas verzuchtte dat de Nederlandse wet- en regelgeving en de praktijk van de verslaggeving achterlopen op die van de Verenigde Staten en Het Verenigd Koninkrijk (Traas, 1999, p. 38)? Deze verzuchting was gebaseerd op impressionistische en anekdotische waarnemingen; er lag geen systematisch empirisch onderzoek aan ten grondslag. ${ }^{6}$ Traas (1999, p. 22) verklaart de door hem gesignaleerde achterstand uit een minder vergaande regelgeving en/of een meer terughoudende verslaggevingscultuur. In navolging van Heijnen typeert Traas (1999, p. 28) Nederland voor wat betreft de wettelijke regelgeving van de jaarverslaggeving als het 'paradijs van vrijblijvendheid'. Wat volgens hem in Nederland ontbreekt, is een systeem van strakke en eenduidige verslaggevingsstandaarden. Verder acht hij het noodzakelijk dat er een verslaggevingscultuur gaat ontstaan bij de ondernemingsleiding, de financiële wereld in het algemeen en de accountants, waarin als ideaal het verschaffen van een helder en compleet inzicht in de actuele positie van een onderneming wordt nagestreefd, met een open discussie over de eraan verbonden risico's (Traas, 1999, p. 29). Zolang aan deze eisen niet wordt voldaan, zal de Nederlandse verslaggevingspraktijk kwalitatief gesproken achter blijven lopen op die in de Angelsaksische landen. Traas (1999, p. 30) acht het noodzakelijk 'politieke keuzes' te maken ten einde de kwaliteitsgap te verkleinen. In het bijzonder dringt hij aan op 'een blauwdruk, opgesteld door een gezaghebbend orgaan dat een duidelijk beeld geeft van wat in Nederland van ondernemingen wordt verwacht betreffende de inhoud van het bestuursverslag en meer in het bijzonder betreffende niet-financiële en toekomstige informatie' (Traas, 1999, p. 38).

Voor wat betreft Traas' opvattingen over gewenste institutionele ontwikkelingen kan gesteld worden dat er in het verstreken decennium 2000-2010 veel in volgens hem gunstige zin is veranderd. Te denken valt hier aan de introductie van de International Financial Reporting Standards (IFRS), de oprichting van de Autoriteit Financiële Markten 
(AFM) en het in werking treden van de Wet toezicht financiële verslaggeving. Dit zijn stuk voor stuk majeure systeemwijzigingen.

Hoe is de gang van zaken geweest voor wat betreft de Nederlandstalige literatuur? Wij noemen hier drie studies: Camfferman en Kamp (2001), Hoogendoorn en Mertens (2001) en Feenstra (2005). Eerstgenoemde studie is een 'compliance'-studie; de tweede is in paragraaf 2 reeds besproken; de derde studie is een metastudie gebaseerd op een viertal 'compliance'-studies.

Camfferman en Kamp (2001) concluderen onder meer dat de meeste beursondernemingen in Nederland in hun directieverslagen weliswaar enige informatie geven over hun strategie en doelstellingen, maar dat er weinig systematiek zichtbaar is in het rapporteren over het al dan niet behalen van financiële en operationele doelstellingen. Vaak wordt een opsomming gegeven van gebeurtenissen zonder analyse van de strategische betekenis. Beschouwingen over meerjarige historische trends blijken vrijwel volledig te ontbreken, evenals het systematisch terugkomen op eerder afgegeven prognoses.

De conclusies van Hoogendoorn en Mertens (2001) over de inhoud van de directieverslagen van Nederlandse beursondernemingen zijn evenmin bemoedigend. Aan de hand van een checklist van 96 door financieel analisten als belangrijk gekwalificeerde informatie-elementen zijn de jaarverslagen van de 60 grootste AEX-fondsen onderzocht. Tot deze 96 informatie-elementen behoren onder meer: een bespreking van de ondernemingsstrategie, een beschrijving van de belangrijkste acquisities en de daarbij behorende motieven, de formulering van langetermijndoelstellingen, een schets van de concurrentiepositie en een bespreking van de aan de strategie verbonden risico's. Gemiddeld genomen verstrekken de 60 ondernemingen slechts $26 \%$ van de gewenste informatie-elementen (Hoogendoorn en Mertens, 2001, p. 414).

Feenstra (2005) heeft een metastudie verricht ter zake van de volgende vier thema's:

- opzet en structuur van het directieverslag;

- toekomstige gegevensverstrekking in het directieverslag;

- stelselwijzigingen;

- bestuurdersbeloningen en optieregelingen.

Op basis van dit onderzoek concludeert hij dat er in Nederland anno 2005 nog steeds veel ruimte bestaat voor verbetering van de kwaliteit van het directieverslag (Feenstra, 2005, pp.16-18). Alleen met betrekking tot het vierde thema lijkt Nederland internationaal gezien niet achter te blijven (p. 19).
Door de geschetste institutionele en verslaggevingsinhoudelijke ontwikkelingen wordt in zekere mate tegemoet gekomen aan de 'eisen' van Traas. Deze conclusie geldt des te meer indien men kijkt naar recente ontwikkelingen bij de RJ, in het bijzonder naar de voorstellen voor een zeer breed opgezet directieverslag (Raad voor de Jaarverslaggeving, 2010). Na eerdere voorstellen in Richtlijn 400 Jaarverslag (RJ, 2003a) en in Handreiking voor Maatschappelijke Verslaggeving (RJ, 2003b) verscheen in 2010 Richtlijnen voor de jaarverslaggeving (grote en middelgrote rechtspersonen). Vooral de paragrafen $920.2 \mathrm{en}$ 920.4 bevatten veel voorstellen ter verbreding van de inhoud van het directieverslag, zoals: besteed aandacht aan strategie, veiligheid en kwaliteit; geef informatie over het gebruik van schaarse goederen, energie en water; licht arbeidsomstandigheden, personeelsbeleid en mensenrechten toe. Dit alles dient volgens een vast sjabloon te worden besproken, omvattende de dialoog met belanghebbenden, het beleid, de organisatie, uitvoering en uitkomsten, alsmede verwachtingen. De toekomst zal leren in hoeverre ondernemingen gehoor geven aan de veelomvattende voorstellen van de RJ. De vraag blijft voorts hangen in hoeverre een en ander kan worden afgedwongen.

\section{Conclusies}

In dit artikel zijn algemeen bekende verslaggevingsschandalen in verband gebracht met het begrip kwaliteit van de verslaggeving, nadat we eerst hebben stilgestaan bij een mogelijke verklaring voor de door ondernemingen gemaakte 'accounting choices'. Wij hebben gewezen op de dominante rol van het 'capital market-based accounting research'-paradigma en als alternatief de gedragstheoretische en sociaalpsychologische theorie van impressiemanagement genoemd. Kwaliteit van de verslaggeving is een belangrijk concept, omdat de beslissingen rond de allocatie van het vermogen van belanghebbende gebruikers van de externe verslaggeving erdoor worden beïnvloed. Daarover zijn de aanhangers van beide paradigmata het eens. Er bestaat evenwel geen eenstemmigheid onder deskundigen over de wijze waarop het begrip kwaliteit geoperationaliseerd dient te worden. In paragraaf 2 worden zowel enkele relatief enge als relatief brede interpretaties besproken. De enge interpretaties beperken zich tot het meten van indicatoren ontleend aan de jaarrekening. De relatief breed opgezette kwaliteitsmetingen omvatten daarnaast metingen van diverse institutionele kenmerken. Bij de keuze van indicatoren voor de kwaliteitsmeting blijkt de algemene managementliteratuur geen grote rol te hebben gespeeld. Wij bepleiten nader onderzoek naar de samenhang.

In de Nederlandse verslaggevingsliteratuur domineert niet het 'capital market-based accounting research'-paradigma, maar een meer juridisch georiënteerde 'compliance'-bena- 
dering. In de afgelopen tien jaren hebben zich belangrijke institutionele en verslaggevingsinhoudelijke ontwikkelingen voorgedaan; van een paradigmatische ansluiting op de internationale verslaggevingsliteratuur is evenwel geen sprake.
Prof. dr. D.W. Feenstra is emeritus hoogleraar Financieel-

administratieve Bedrijfseconomie aan de faculteit Economie

en Bedrijfskunde van de Rijksuniversiteit Groningen. ${ }^{7}$

\section{Noten}

I. In BW 2 titel 9 worden de directieverslagen aangeduid met de term jaarverslagen. Wij hanteren beide termen als synoniemen. Het geheel van jaarrekening en jaarverslag noemen wij gemakshalve het jaarrapport. Het jaarrapport vormt de kern van de externe verslaggeving. 2 Klaassen (2004) vermeldt in zijn afscheidscollege enkele interessante feiten over de groei van de verslaggeving in Nederland. Zo is de gemiddelde omvang van de toelichting op de jaarrekening van de winnaars van de Henri-Sijthoff prijs over de periode 1970-2010 van 3 pagina's gestegen tot 22 pagina's. Over dezelfde periode groeide het directieverslag van gemiddeld 9 pagina's tot gemiddeld 29 pagina's, waarbij de groei in omvang zich vooral manifesteerde in de vorm van meer aandacht voor de thema's missie \& strategie, corporate governance, maatschappelijk verantwoord ondernemen en risicoanalyses. 3 Jones en Shoemaker (1994) hebben 26 leesbaarheidsstudies gereviewd waarin het jaarrapport centraal stond. In deze leesbaarheidsstudies wordt de cognitieve moeilijkheidsgraad van teksten door middel van diverse leesbaarheidsformules onderzocht. Hoewel er veel kritiek bestaat op dergelijke formules, heerst er wel consensus over de opvatting dat jaarrapporten moeilijk tot zeer moeilijk leesbaar zijn (Beattie et al., 2004). 4 In de managementititeratuur zijn nog vele andere voorbeelden te vinden. Wij noemen hier slechts: McKinsey's 7-S Model, de Balanced Scorecard, het EFQM- en INK-Model, en de modellen ontwikkeld door adviesbureaus zoals KPMG en Twijnstra. 5 Deze opvatting was anno 2002 evenwel reeds lang achterhaald door ontwikkelingen binnen het vakgebied economie. Zie voor ontwikkelingen in de relatie tussen accounting en bedriffseconomie Bouma en Feenstra (1997).

6 Desondanks krijgt de bewering dat er een kwaliteitsgap bestaat ten nadele van Nederland extra gewicht indien men kennis neemt van het deponeringsgedrag van Nederlandse ondernemingen bij de Kamer van Koophandel. In Nederland wordt de jaarrekening c.a. namelijk structureel te laat gedeponeerd. Zie Feenstra (2007) en de aldaar opgenomen verwijzingen naar NRC Handelsblad en Het Financieele Dagblad. Zo had slechts 19\% van de 584.000 deponeringsplichtige ondernemingen eind juni 2005 aan deponeringsverplichtingen over 2004 voldaan. Bijna 60.000 ondernemingen hadden op dat moment zelfs over 2003 nog niets gedeponeerd! Een kwalijke gang van zaken. En dan te bedenken dat de FIOD-ECD nog geen 1000 processen per jaar weet te produceren, die vervolgens veelal niet tot boetes leiden! Het lijkt erop dat niet alleen misdaad loont, zoals de zegswijze ons wil doen geloven, maar ook het plegen van het economisch delict 'niet deponeren'. Anno 2010 is nog niet duidelijk in hoeverre de sinds 1 januari 2007 in werking getreden Wet toezicht financiële verslaggeving en het optreden van de Autoriteit Financiële Markten (AFM) tot substantiële verbeteringen hebben geleid. Zie voor recente gegevens Vlaming (2010). Over de mogelijk zeer ernstige financiële consequenties bij het niet naleven van de deponeringsplicht in het geval van faillissement lijken ondernemers zich geen zorgen te maken.

$\mathbf{Z}$ De auteur dankt Jan van Helden, Martin Hoogendoorn, Chris Knoops en enkele anonieme beoordelaars voor de kanttekeningen en suggesties bij eerdere versies van dit artikel.

\section{Literatuur}

- AICPA (American Institute of Certified Public Accountants) (1994), Improving business reporting - A customer focus (the Jenkins report), New York, NY: American Institute of Certified Public Accountants.

- ASB (Accounting Standards Board) (2003), Operating and financial review, Londen: Accounting Standards Board.

- Ball, R. en L. Shivakumar (2005), Earnings quality in UK private firms: Comparative loss recognition timeliness, Journal of Accounting and Economics, vol. 39, no. 1, pp. 83-128. Beattie, V., B. Mclnnes en S. Fearnley (2004), A methodology for analysing and evaluating narratives in financial reports: A comprehensive descriptive profile and metric for disclosure quality attributes, Accounting Forum, vol. 28, no. 3, pp. 205-236.

- Bernard, V.L. (1989), Capital markets research in accounting during the 1980's: A critical review, Board of Trustees of the University of Illinois, Champaign.

- Botosan, C.A. (1997), Disclosure level and the cost of equity capital, The Accounting Review, vol. 72, no. 3, pp. 323-349.

Botosan, C.A. (2006), Disclosure and the cost of capital. What do we know?, Accounting and Business Research, International Accounting Policy Forum, pp. 31-40.

- Bouma, J.L. en D.W. Feenstra (1997), Accounting and business economics traditions in the Netherlands, The European Accounting
Review, vol. 6, no. 2, pp.175-197.

-Camfferman, C. en B. Kamp (2001), Het directieverslag: opzet en structuur, in: J.A.C.M. Koevoets, G.M.H. Mertens en R.G.A. Vergoossen (redactie), Het jaar 2000 verslagen (pp. 15-34), Deventer/Amsterdam: Kluwer/Koninklijk NIVRA.

- Clatworhty, M. en M.J. Jones (2001), The effect of thematic structure on the variability of annual report readability, Accounting Auditing and Accountability Journal, vol. 14 , no. 3 , pp. 311-326.

- Collins, J.C. en J.I. Porras (1994), Built to

last, Londen: Random House.

- Dechow, P.M. en C.M. Schrand (2004),

Earnings quality, C.F.A. Institute. 
-FASB (Financial Accounting Standards Board) (2001), Business and financial reporting. Challenges from the new economy.

- Feenstra, D.W. (2005), De slag om de inhoud van het directieverslag: de directie verslagen?, in: M. Bollen, R. Beeres, J. Soeters en R. Smits (redactie), Toga's en Baretten (pp. 13-22), Breda: Koninklijke Militaire Academie. - Feenstra, D.W. (2007), Over het (niet) naleven van de deponeringsplicht, in: D. Swagerman en M. Galema (redactie), De controller in perspectief (pp. 72, 73), Groningen: Rijksuniversiteit Groningen.

- Fields, T., T. Lys en L. Vincent (2001), Empirical research on accounting choice, Journal of Accounting and Economics, vol. 31 , nos. 1-3, pp. 255-307.

- Francis, J., S. Huang, I. Khurana en R. Pereira (2009), Does corporate transparency contribute to efficient resource allocation?, Journal of Accounting Research, vol. 47, no. 4, pp. 943989.

- Francis, J., I. Khurana en R. Pereira (2005), Disclosure incentives and effects on cost of capital around the world, The Accounting Review, vol. 80, no. 4, pp. 1125-1162.

- Francis, J., P. Olsson en K. Schipper (2006), Earnings quality, Foundations and Trends in Accounting, vol. 1, no. 4, pp. 259-340.

-Francis, J., K. Schipper en L. Vincent (2005), Earnings and dividends informativeness when cash flow rights are separated from voting rights, Journal of Accounting and Economics, vol. 39, pp. 329-360.

Gaio, C. en C. Raposo (in press), Earnings quality from valuation: international evidence, Accounting and Finance, doi: 10.1111/j.1467-629X.2010.00362.x.

- Geus, A. de (1997), De levende onderneming, Schiedam: Scriptum.

- Hoogendoorn, M.N. en G.M.H. Mertens (2001), Kwaliteit van de financiële verslaggeving in Nederland, Maandblad voor Accountancy en Bedrifseconomie, vol. 75, no. 10, pp. 406-420. - Hooghiemstra, R. (2000), Corporate communication and impression managementNew perspectives why companies engage in social reporting, Journal of Business Ethics, vol. 27, nos. 1-2, pp. 55-68.

- IASB (International Accounting Standards Board) (2006), Discussion paper: Preliminary views on an improved Conceptual Framework for Financial Reporting.
- IASB (International Accounting Standards Board) (2008), Exposure Draft: An improved Conceptual Framework for Financial Reporting.

- IASB (International Accounting Standards Board) (2010), Conceptual Framework for Financial Reporting 2010

- ICAEW (Institute of Chartered Accountants in England and Wales) (2003), New reporting models for business, Londen: Institute of Chartered Accountants in England and Wales. - Jones, M.J. en P.A. Shoemaker (1994), Accounting narratives: A review of empirical studies of content and readability, Journal of Accounting Literature, vol. 13, pp. 142-184. - Kamp, B. (2002), Kwaliteit van de winst, Maandblad voor Accountancy en Bedrijfseconomie, vol. 76, no. 7/8, pp. 328-336. - Kempen, P.M. (1989), Bedrijfsdiagnose alias Management Audit, Alphen aan den Rijn, Brussel: Samsom.

- Klaassen, J. (2004), Goede jaarverslaggeving, vroeger en nu, Afscheidscollege, Vrije Universiteit Amsterdam. - Knoops, C.D. (2001), Het meten van de kwaliteit van de financiële verslaggeving, Maandblad voor Accountancy en Bedrijfseconomie, vol. 75, no. 10, pp. 431-443.

- Knoops, C.D. (2010),

Verslaggevingstheorieën: Een

wetenschapsfilosofische analyse, Dissertatie Erasmus Universiteit Rotterdam.

- Lang, M.H. en R.J. Lundholm (2000), Voluntary disclosure and equity offerings: Reducing information asymmetry or hyping the stock?, Contemporary Accounting Research, vol. 17, no. 4, pp. 623-669.

- Leeflang, P.S.H. (1993), Probleemgebied Marketing: deel 1, Analyse van de omgeving derde druk, Leiden/ Antwerpen: Stenfert Kroese.

- Leuz, C., D. Nanda en P. Wysocki (2003), Earnings management and investor protection: An international comparison, Journal of Financial Economics, vol. 69, no. 3, pp. 505-527.

- Leuz, C. en R. Verrecchia (2003), The economic consequences of increased disclosure, Journal of Accounting Research, vol. 38, Supplement, pp. 91-124.

- Lev, B. en J.A. Ohlson (1982), Market-based empirical research in accounting: A review, interpretation and extension, Journal of Accounting Research, vol. 20, Supplement, pp.249-322.
- Maandblad voor Accountancy en Bedrijfseconomie (2010), Het jaar 2008 verslagen, vol. 84, no. 1/2, pp. 4-98. - Maandblad voor Accountancy en Bedrijfseconomie (2011), Het jaar 2009 verslagen, vol. 85, no. 1/2, pp. 4-116.

- Merkl-Davies, D.M. en N. Brennan (2007), Discretionary disclosure strategies in corporate narratives: Incremental information or impression management? Journal of Accounting Literature, vol. 26, pp. 116-196.

Mulford, C.W. en E.E. Comiskey (2002), The financial numbers game. Detecting creative financial accounting practices, New York: John Wiley.

- Myers, J., L. Myers en D.J. Skinner (2007), Earnings momentum and earnings management, Journal of Accounting, Auditing, and Finance, vol. 22, no. 2, pp. 249-284.

- Nelson, M., J. Elliot en R. Tarpley (2002), Evidence from auditors about managers' and auditors' earnings management decision, The Accounting Review, vol. 77, Supplement, pp. 175-202.

- Nobes, C. en R. Parker (2002), Comparative international accounting, 7e druk, Essex: Pearson Education Limited.

- Peters, Th. J. en R.H. Waterman jr. (1982), Excellente ondernemingen, Utrecht/ Antwerpen: Veen.

- Raad voor de Jaarverslaggeving (2003 a), Richtlijn 400 Jaarverslag (2003), Deventer: Kluwer. Aangepast in 2010.

Raad voor de Jaarverslaggeving (2003 b), Handreiking voor Maatschappelijke Verslaggeving, Deventer: Kluwer. Aangepast in 2010

- Raad voor de Jaarverslaggeving (2010), Richtlijnen voor de jaarverslaggeving (grote en middelgrote rechtspersonen), Jaareditie 2010.

- Radebaugh, L.H. en S.J. Gray (2002), International accounting and multinational enterprises, 5e druk, John Wiley and Sons Inc. - SEC (Securities and Exchange Commission) (2003), Final rule: Disclosure in management's discussion and analysis about off-balance sheet arrangements and aggregate contractual obligations, Washington D.C.

- Skinner, D.J. en R.G. Sloan (2002), Earnings surprises, growth expectations and stock returns, Review of Accounting Studies, vol. 7 , pp. 289-312. 
The Accounting Review (2002), The quality of earnings, vol. 77, Supplement 2002.

- Traas, L. (1999), Om de kwaliteit van de Nederlandse verslaggeving, Management Control \& Accounting, vol. 3, nos. 2 en 3, resp. pp. 22-30 en 30-39.
- Verriest, A. (2009), Institutions, firm profitability and financial reporting quality, Dissertatie Katholieke Universiteit Leuven. - Vlaming, H. (2010), Duwen en trekken, De Accountant, vol. 116, no. 1, pp. 28-31.
Witteloostuijn, A. van (1999), De anorexiastrategie, Amsterdam/Antwerpen: De Arbeiderspers.

Zwan, A. van der (1990), Koplopers

en achterblijvers, Baarn: Anthos.

\section{Bijlage 1 Kwalitatieve eigenschappen van informatie: hoofdlijnen}

In diverse 'conceptual frameworks' van de IASB en van regelgevende instanties in verschillende landen wordt expliciet ingegaan op de kwalitatieve eigenschappen van informatie. Zo onderkent bijvoorbeeld de Amerikaanse FASB in SFAC 2 al sinds het begin van de jaren tachtig de volgende kwalitatieve eigenschappen: relevantie en betrouwbaarheid. Deze twee eigenschappen worden van primair belang geacht; er worden diverse andere eigenschappen van afgeleid. Relevantie omvat conform SFAC 2 de volgende aspecten: voorspellende waarde, 'feedback'-waarde en tijdigheid. Betrouwbaarheid omvat het volgende: getrouwe weergave, controleerbaarheid en neutraliteit. Naast relevantie en betrouwbaarheid onderkent SFAC2 nog de eigenschappen gelijktijdige stelselmatigheid en volgtijdige stelselmatigheid, maar deze twee eigenschappen worden van secundair belang geacht. Naast de twee primaire en de twee secundaire kwalitatieve eigenschappen worden nog twee 'randvoorwaarden' genoemd, namelijk: de kosten van de informatieverstrekking mogen niet groter zijn dan de baten en het materialiteitsbeginsel. Er dient naar gestreefd te worden al deze beginselen zo goed mogelijk tot hun recht te laten komen; een bepaalde 'trade-off zal veelal niet te vermijden zijn. Het IASC, de rechtsvoorganger van de IASB, publiceerde in 1989 een enigszins afwijkend 'conceptual framework' waarin expliciet wordt ingegaan op kwalitatieve kenmerken. Een Nederlandse vertaling hiervan door de Raad voor de Jaarverslaggeving is bekend geworden onder de benaming Stramien. Bij een vergelijking van diverse 'conceptual frameworks' blijken er tal van (kleine) verschillen te bestaan, met name voor wat betreft de veronderstelde hiërarchie van de verschillende kenmerken.
Sinds de invoering van de IFRS werken de FASB en de IASB samen in een 'conceptual framework'-project. Begin 2010 waren er onder andere een 'discussion paper' (IASB, 2006) en een 'exposure draft' (IASB, 2008) gepubliceerd over de doelstellingen van de financiële verslaggeving en de kwalitatieve eigenschappen van informatie. Vanwege deze convergentietendens gaan wij hier niet dieper en gedetailleerder in op de overeenkomsten en verschillen van de vele concepten die in de diverse rapporten worden genoemd (zie Knoops, 2010, pp. 100-102). Inmiddels is een definitieve versie van de conceptversies gepubliceerd, getiteld: Conceptual Framework for Financial Reporting 2010 (IASB, 2010).

Het convergentieproces is medio 2010 nog niet afgerond. Knoops (2010) geeft in voetnoot 73 op p. 94 zeer gedetailleerd weer welke ontwikkelingen zich sinds medio 2008 in dit verband hebben voltrokken. De stand van zaken is momenteel zo dat de volgende hiërarchie van kwalitatieve kenmerken wordt voorgesteld (Knoops, 2010, pp. 101,102):

- fundamentele kwalitatieve eigenschappen van informatie (namelijk relevantie en getrouwe weergave, 'faithful representation'), die ertoe leiden dat de informatie nuttig is ten behoeve van het nemen van beslissingen betreffende de allocatie van middelen ('resources');

- aanvullende kwalitatieve eigenschappen (namelijk vergelijkbaarheid, verifieerbaarheid, tijdigheid en begrijpelijkheid).

Het is opvallend dat begrippen als betrouwbaarheid ('reliability'), 'substance over form' en voorzichtigheid ('conservatism') niet langer deel uitmaken van het Framework. 


\section{Aanbesteding en sturing van openbaarvervoerconcessies in het licht van opbrengstrisico's en ontwikkelverantwoordelijkheid}

Jan Bosker

SAMENVATTING In het openbaar vervoer in Nederland is sprake van marktwerking in de vorm van concurrentie om de weg. De decentrale overheid (provinciaal of regionaal) heeft de wettelijke taak om openbaarvervoerconcessies (OV-concessies) te verlenen aan vervoerders door middel van aanbestedingen. In die aanbestedingen definieert de concessieverlenende overheid onder meer de rolverdeling tussen zichzelf en de concessieverkrijgende vervoerder.

Een belangrijke vraag die zich daarbij voordoet is met welke rolverdeling tussen de concessieverlenende overheid en de concessieverkrijgende vervoerder de doelstellingen met betrekking tot het openbaarvervoerbeleid van de betrokken overheid het beste gediend zijn. Moet de overheid de verantwoordelijkheid nemen voor de productontwikkeling? Wie draagt het reizigersopbrengstrisico, de overheid of de vervoerder? En wat betekent het antwoord op die vragen voor de wijze van aanbesteden en beheren door de concessieverlenende overheid?

\section{RELEVANTIE VOOR DE PRAKTIJK Decentrale overheden (provinciaal en regionaal)} hebben een wettelijke taak om openbaarvervoerconcessies te verlenen door middel van aanbestedingen. De keuzes die overheden daarbij maken, hebben gevolgen voor kosten, risico's en sturing. en het railvervoer geldt een aanbestedingsplicht, waarbij er concurrentie is om de weg. Het aanbesteden van het openbaar vervoer in de vorm van concessies is een wettelijke taak van (decentrale) overheden. Een zeer bepalende keuze hierbij is of de verantwoordelijkheid voor productontwikkeling en opbrengstrisico bij de opdrachtgevende overheid, dan wel bij de opdrachtnemende vervoerder komt te liggen. Deze keuze heeft niet alleen grote gevolgen voor de rollen als opdrachtgever en opdrachtnemer, maar ook voor sturing en control van de concessie.

In dit artikel probeer ik de volgende vraag te beantwoorden: met welke rolverdeling tussen de concessieverlenende overheid en de concessieverkrijgende vervoerder worden de doelstellingen met betrekking tot het openbaarvervoerbeleid van de betrokken overheid het beste gediend? De rolverdeling betreft enerzijds de mate van verantwoordelijkheid voor productontwikkeling, bijvoorbeeld in de vorm van nieuwe buslijnen, frequentiewijzigingen en tarievenbeleid en anderzijds de verdeling van de risico's van lagere of hogere dan geplande reizigersopbrengsten. Het gekozen perspectief daarbij is dat van de concessieverlenende overheid. Belicht zijn met name de bedrijfseconomische overwegingen en de sturing- en controloverwegingen.

Met een achtergrondenanalyse op basis van beschikbare literatuur en documenten is een vergelijkende casestudie uitgevoerd. In totaal zijn er vier cases betrokken in het onderzoek; twee aanbestedingen van ov-concessies met het opbrengstrisico bij de vervoerder en twee aanbestedingen met het opbrengstrisico bij de opdrachtgevende overheid.

Het artikel is verder als volgt opgebouwd. In paragraaf 2 schets ik de context waarbinnen aanbestedingen voor 